\title{
Aplikasi Waktu Pembukaan Okulasi dan Pemotongan Batang Bawah terhadap Pertumbuhan Awal Jeruk Siam Madu (Citrus nobilis L.)
}

\author{
Budi Siswanto ${ }^{1}$, Praptiningsih G.A ${ }^{2}$, Sri Rahayu ${ }^{3}$ \\ ${ }^{I}$ Program Studi Agroteknologi, Universitas Merdeka Madiun, Jl. Serayu No.79, Madiun, 663133 \\ E-mail: budisiswa0107@gmail.com \\ ${ }^{2}$ Program Studi Agroteknologi, Universitas Merdeka Madiun, Jl. Serayu No.79, Madiun, 663133 \\ E-mail: praptiningsih@unmer-madiun.ac.id \\ ${ }^{3}$ Program Studi Agroteknologi, Universitas Merdeka Madiun, Jl. Serayu No.79, Madiun, 663133 \\ E-mail: srirahayu@unmer-madiun.ac.id
}

\begin{abstract}
The percentage of failure to multiply "Siam madu" oranges by grafting in the rainy season is around $50 \%$ to 80 \%. The purpose of the study was to determine the interaction of rootstock pruning length and time of grafting plastic opening on the initial growth of "Siam madu" oranges (Citrus nobilis L). The study used a factorial experiment based on a randomized block design $(\mathrm{RAK})$. The first factor was the length of pruning $(P)$ were, $P 1=5 \mathrm{~cm}$ above of patch eye with 0.5 stems, $P 2=5 \mathrm{~cm}$ above of patch eye, and $P 3=10 \mathrm{~cm}$ from the shoot. The second factor is the opening time of grafting plastic $(B)$ were $B 1=25$ days after grafting $(D A G), B 2=30 D A G$ and B3 $=35 D A G$. Observation parameters included the percentage of grafting growth, time of shoot appearance, number of leaves, length of grafting shoots, and leaf area. The results showed that there was a significant interaction between the treatment of rootstock pruning length (P) and plastic opening time (B) to shoot appearance time, the number of leaves, shoot length, and leaf area. The best results of the combination variable treatment observed were achieved by the treatment of rootstock pruning length of $5 \mathrm{~cm}$ above of patch eye and opening time of grafting plastic 25 DAG (P2B1), namely shoot emergence time (30.20 days), shoot length 46 DAG $(21.06 \mathrm{~cm})$. In addition, the number of leaves was $46 \mathrm{DAG}(10.66)$ and leaf area (225.96 $\mathrm{mm} 2)$.
\end{abstract}

Keywords - : grafting percentage growing; root stock; scions; vegetative propagation.

\section{PENDAHULUAN}

Sebagian besar tanaman jeruk dapat tumbuh di seluruh wilayah Indonesia. Salah satunya adalah jeruk siam madu (Citrus nobilis L.). Jeruk ini mampu tumbuh dan berproduksi mulai dari dataran rendah sampai dataran tinggi (Purba dan Purwoko, 2019). Data Badan Pusat Statistika (2019) menunjukkan bahwa produksi jeruk dari tahun 2018 sampai tahun 2019 mengalami kenaikan yaitu 2 408,029 t menjadi 2 444,518 t. Meskipun produksi jeruk naik namun jumlah impor jeruk dari tahun 2018 sampai 2019 juga mengalami kenaikkan yaitu 95 962,09 t menjadi 151 243,83 t. Konsumsi jeruk per kapita per tahun juga mengalami peningkatan dari $3,28 \mathrm{~kg}$ menjadi $4,43 \mathrm{~kg}$.

Faktor pendorong dalam meningkatkan produksi dan produktivitas jeruk dapat dilakukan dengan pengembangan bibit yang bermutu dan berkualitas. Gusriani et al. (2019), menyatakan bahwa kunci keberhasilan pengembangan buah buahan, sangat ditentukan oleh ketersediaan bibit yang bermutu. Salah satu pengembangan bibit dapat dilakukan dengan teknik perbanyakan tanaman. Namun teknik ini membutuhkan bahan perbanyakan yang tepat untuk menghasilkan jeruk dengan sifat yang diinginkan dan cepat berbuah. Tanaman jeruk dapat diperbanyak secara generatif maupun vegetatif. Perbanyakan jeruk secara generatif memiliki kelemahan yaitu membutuhkan waktu lebih lama untuk menghasilkan buah dan rendahnya tingkat kesamaan sifat dari induknya dibandingkan dengan bibit yang berasal dari perbanyakan vegetatif (Hakim et al., 2019). Hal ini akan berdampak pada pemenuhan kebutuhan buah jeruk jika harus menunggu dalam waktu yang lama (Nurwahyuni et al., 2012).

Perbanyakan vegetatif merupakan cara perbanyakan yang seringkali digunakan dalam penyediaan bibit tanaman buah. Teknik perbanyakan vegetatif memiliki berbagai variasi yaitu stek, sambung, penyusunan, cangkok dan okulasi (Prastowo et al., 2006). Perbanyakan vegetatif yang sering dilakukan pada tanaman jeruk adalah teknik okulasi. Teknik ini memiliki tiga macam yaitu okulasi biasa, okulasi-T dan okulasi irisan (Setiono dan Supriyanto, 2004). Penggunaan metode Chip-budding sering digunakan untuk perbanyakan okulasi. Penyediaan bibit secara okulasi telah banyak dikembangkan, terutama dalam usaha perbanyakan bibit-bibit jeruk unggul yang cepat dalam menghasilkan buah. Bibit hasil okulasi secara umum dapat dikatakan paling diminati karena tanaman hasil okulasi merupakan perpaduan dua sifat unggul. Perolehan bibit okulasi merupakan gabungan dari dua sifat beda terdiri dari batang atas (entres) dan batang bawah (root stock) (Jayanti et al., 2015). Pada umumnya jenis jeruk yang digunakan sebagai batang bawah diantaranya jenis jeruk Volkameriana, Citrumello 4475, Troyer citrage, rough lemon, Japance citroen (Sugiyatno, 2017).

Permasalahan yang dihadapi penangkar bibit jeruk adalah tingkat kegagalan hasil perbanyakan tanaman jeruk yang cukup tinggi jika dilakukan saat musim penghujan. Basri (2009) melaporkan rendahnya tingkat keberhasilan sambungan pertautan disebabkan oleh factor lingkungan yaitu curah hujan. Tingginya curah hujan dan frekuensi (hari) hujan yang terjadi setelah 
Website : http://agritek.unmermadiun.ac.id/index.php/agritek

penyambungan sebagai faktor penyebab utama terhadap tingginya tingkat kematian entres. Hal tersebut mengakibatkan penangkar bibit jeruk berhenti untuk melakukan okulasi. Akibatnya perbanyakan bibit jeruk hanya dilakukan pada saat musim kemarau yang waktunya sulit diprediksi. Tingkat kegagalan yang tinggi saat musim penghujan diduga dipengaruhi oleh masa dormansi pada mata entres.

Dormansi pada okulasi terjadi akibat dormansi secara fisik dan dormansi tunas lateral. Dormansi tersebut mengakibatkan entres tempelan mongering dan tidak tumbuhnya tunas entres. Beberapa faktor yang mendorong berhentinya dormansi adalah pemotongan batang bawah dan waktu pembukaan plastik pada entres yang tepat pada musim penghujan. Menurut Rokayat et al. (2017) bahwa pemangkasan batang bawah dapat menghentikan dormansi pada tunas lateral. Sedangkan Margarenta et al. (2019) mengemukakan bahwa kemunculan tunas lateral terhambat dikarenakan adanya gangguan dormansi secara fisik yaitu pengikatan entres dengan plastik. Berdasarkan permasalahan tersebut, penelitian ini bertujuan untuk mengaplikasikan metode okulasi yang tepat dan benar pada perbanyakan jeruk saat musim penghujan. Sehingga penangkar bibit jeruk tidak terlalu terikat dengan musim untuk melakukan perbanyakan secara okulasi.

\section{METODE PENELITIAN}

Penelitian dilaksanakan di Desa Kranggan RT. 01 RW.01 Kecamatan Geger Kabupaten Madiun pada bulan Desember 2019 - Februari 2020 saat musim penghujan. Pada garis lintang 740’06.8’'S dan bujur 111³1'25.8”E. Bahan tanam yang digunakan adalah tanaman jeruk Japance Citroen sebagai batang bawah (sebanyak 135 bibit umur 6 bulan) dan jeruk siam madu (Citrus nobilis L.) sebagai entres (sebanyak 135). Penelitian menggunakan polybag dan sebagai media tanam berupa campuran tanah dan sekam dengan perbandingan 3:1 dan diberi pupuk organik.

Metode penelitian menggunakan percobaan Faktorial yang disusun berdasarkan Rancangan Acak Kelompok (RAK) terdiri dua faktor diulang tiga kali. Faktor pertama adalah panjang pemangkasan $(\mathrm{P})$ terdiri atas tiga perlakuan $\mathrm{P} 1=5 \mathrm{~cm}$ diatas mata tempel dengan 0,5 batang, $\mathrm{P} 2=5 \mathrm{~cm}$ diatas mata tempel dan $\mathrm{P} 3=10 \mathrm{~cm}$ dari pucuk. Faktor kedua adalah waktu pembukaan plastik okulasi (B) meliputi perlakuan B1= 25 Hari Setelah Okulasi (HSO), B2=30 HSO dan B3= 35 HSO.

Data hasil pengamatan dianalisis ragam menggunakan Statistical Product and Service Solutions (SPSS) versi 25 untuk mengetahui ada tidaknya pengaruh panjang pemangkasan dan waktu buka plastik okulasi. Jika terdapat perbedaan yang signifikan antar faktor maka dilanjutkan dengan uji Duncan pada taraf $\alpha=5 \%$ untuk melihat signifikansi perlakuan-perlakuan yang berbeda terhadap variabel pengamatan. Pengamatan dilakukan pada variabel persentase okulasi tumbuh (\%) pada 60 hari setelah okulasi, waktu muncul tunas (hari) yaitu mulai saat okulasi sampai pada saat mata entres pecah, jumlah daun (helai) dimulai dari $46 \mathrm{HSO}, 53 \mathrm{HSO}$, dan $60 \mathrm{HSO}$, panjang tunas okulasi (cm) dimulai dari pangkal tunas (dari perisai okulasi) sampai pangkal daun terakhir yang dilakukan pada $46 \mathrm{HSO}, 53 \mathrm{HSO}$, dan $60 \mathrm{HSO}$, dan variabel luas daun diukur menggunakan metode kertas millimeter.

\section{III.HASIL DAN PEMBAHASAN}

\section{A. Persentase Okulasi Tumbuh (\%)}

Analisis statistika menunjukkan tidak terdapat interaksi antara panjang pemangkasan batang bawah (P) dengan waktu pembukaan plastik okulasi (B) terhadap persentase okulasi tumbuh. Demikian pula panjang pemangkasan batang bawah maupun waktu pembukaan plastik okulasi masing-masing tidak berpengaruh nyata terhadap persentase okulasi tumbuh. Hasil pengamatan tersaji pada Tabel 1 .

Tabel 1.

Rata-rata Persentase Okulasi Tumbuh (\%) 60 HSO pada Panjang Pemangkasan Batang Bawah dan Waktu Pembukaan Plastik Okulasi

\begin{tabular}{cc}
\hline Perlakuan & Persentase Okulasi Tumbuh (\%) \\
\hline P1 & 100 \\
P2 & 100 \\
P3 & 100 \\
\hline & tn \\
B1 & 100 \\
B2 & 100 \\
B3 & 100 \\
\hline & tn
\end{tabular}

Tabel 1 menunjukkan rata-rata persentase okulasi tumbuh yang sama yaitu $100 \%$ untuk semua perlakuan baik pada faktor panjang pemangkasan batang bawah (perlakuan P1, P2, P3) maupun faktor waktu pembukaan plastik okulasi (B1, B2, B3). Artinya pada 60 HSO terdapat keberhasilan dalam penyambungan batang bawah dan batang atas. Dengan kata lain batang atas kompatibel dengan batang bawah. Hal ini disebabkan prosedur teknis sudah dilakukan dengan benar dan tepat. Faktor teknis yang mempengaruhi keberhasilan okulasi adalah keahlian dalam kecepatan menyambung yang merupakan pencegahan paling baik terhadap infeksi penyakit dan kerusakan pada cambium. Selain itu kesempurnaan alat dalam penyambungan memerlukan ketajaman dan kebersihan alat, tali pengikat yang tipis dan lentur (Musthofa, et al., 2019). 
Website : http://agritek.unmermadiun.ac.id/index.php/agritek

\section{B. Waktu Muncul Tunas (hari)}

Faktor panjang pemangkasan batang bawah (P) dan waktu pembukaan plastik okulasi (B) secara bersama-sama berpengaruh terhadap waktu muncul tunas. Interaksi rata-rata panjang pemangkasan batang bawah (P) dan waktu pembukaan plastik okulasi (B) dapat dilihat pada Gambar 1 .

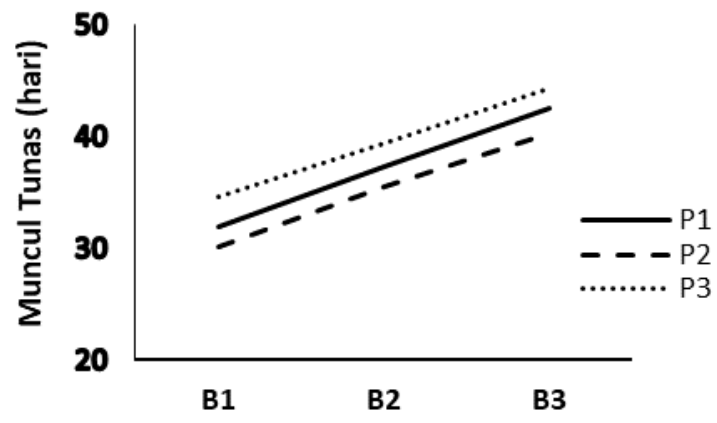

Gambar 1.

Rata-rata Waktu Muncul Tunas (hari) pada Panjang Pemangkasan Batang Bawah (P) dan Waktu Pembukaan Plastik Okulasi (B)

Gambar 1 menunjukkan rata-rata waktu muncul tunas paling cepat didapat dari kombinasi perlakuan pemangkasan $5 \mathrm{~cm}$ diatas mata tempel dengan waktu pembukaan plastik okulasi umur 25 HSO (P2B1 yaitu 30,20 hari. Sedangkan rata-rata waktu muncul tunas paling lambat didapatkan dari perlakuan pemangkasan $10 \mathrm{~cm}$ dari pucuk dengan waktu pembukaan plastik okulasi umur 35 HSO (P3B3) yaitu 44,27 hari. Pembukaan plastik okulasi yang lebih awal mengakibatkan pecah tunas lebih cepat. Pertumbuhan mata tunas yang dibatasi secara fisik yaitu penutupan entres dengan plastik dapat menghambat pertumbuhan mata tunas. Pembatasan fisik tersebut dapat dikatakan sebagai dormansi secara fisik. Bibit dorman merupakan kondisi ketika mata tunas okulasi masih dalam keadaan hijau namun belum atau tidak dapat berkembang menjadi tunas tanaman (Sariningtias et al., 2014).

\section{Panjang Tunas (cm)}

Terdapat interaksi antara panjang pemangkasan batang bawah (P) dengan waktu pembukaan plastik okulasi (B) terhadap panjang tunas umur $46 \mathrm{HSO}, 53 \mathrm{HSO}$, dan $60 \mathrm{HSO}$ yang disajikan pada Tabel 2.

Tabel 2.

\begin{tabular}{|c|c|c|c|c|}
\hline & Perlakuan & $46 \mathrm{HSO}$ & 53 HSO & 60 HSO \\
\hline & P1B1 & $19,39 \mathrm{~h}$ & $28,64 \mathrm{f}$ & $37,63 \mathrm{~d}$ \\
\hline & P1B2 & $11,16 \mathrm{e}$ & $20,28 \mathrm{~d}$ & $26,74 \mathrm{~b}$ \\
\hline & P1B3 & $4,37 \mathrm{~b}$ & $13,37 \mathrm{~b}$ & $22,38 \mathrm{a}$ \\
\hline & P2B1 & $21,06 \mathrm{i}$ & $28,82 \mathrm{f}$ & $37,92 \mathrm{~d}$ \\
\hline & $\mathrm{P} 2 \mathrm{~B} 2$ & $13,64 \mathrm{f}$ & $22,67 \mathrm{e}$ & $31,66 \mathrm{c}$ \\
\hline & P2B3 & $7,66 \mathrm{c}$ & $16,77 \mathrm{c}$ & $25,78 \mathrm{~b}$ \\
\hline & P3B1 & $14,74 \mathrm{~g}$ & $23,73 \mathrm{e}$ & $32,74 \mathrm{c}$ \\
\hline & P3B2 & $8,91 \mathrm{~d}$ & $17,98 \mathrm{c}$ & $26,98 \mathrm{~b}$ \\
\hline & P3B3 & $2,25 \mathrm{a}$ & $11,36 \mathrm{a}$ & 20,36 a \\
\hline
\end{tabular}

Hasil pengamatan pada Tabel 2 menjelaskan bahwa panjang tunas bervariasi dari (2,25-21.06) $\mathrm{cm}$ pada $46 \mathrm{HSO},(11,36$ $28,82) \mathrm{cm}$ pada 53 HSO dan $(20,36-37,92) \mathrm{cm}$ pada 60 HSO. Pada awal pengamatan panjang tunas terbaik dicapai oleh perlakuan P2B1 yaitu 21,06 cm namun pada pengamatan berikutnya (53 HSO dan $63 \mathrm{HSO}$ ) tidak berbeda nyata dengan perlakuan P1B1. Sedangkan yang terpendek adalah perlakuan panjang pemangkasan $10 \mathrm{~cm}$ dari pucuk pada waktu pembukaan plastik okulasi umur 35 HSO (P3B3) yaitu 2,25 cm dan sampai pengamatan 60 HSO perlakuan P3B3 masih memiliki panjang tunas terendah meskipun tidak berbeda nyata dengan P1B3. Terlihat bahwa terjadi kecenderungan penurunan panjang tunas dari 53 HSO ke 60 HSO yaitu sebesar 5.26\% pada P2B1 dan $16.32 \%$ pada P1B1. Pertambahan panjang tunas menurun seirng dengan bertambahnya waktu. Penghambatan panjang tunas entres disebabkan oleh pertumbuhan tunas lateral lain pada batang bawah. Adinugraha et al. (2017) menyatakan jumlah tunas yang sedikit menghasilkan tingkat pertambahan panjang tunas lebih besar atau sebaliknya. Selain itu, kemungkinan penurunan perpanjangan tunas lateral dikarenakan jumlah auksin yang terlalu tinggi pada pucuk. Tingginya auksin pada pucuk akan menyebabkan dominansi apikal (Hidayati, 2009). Menurut Mardiyah $e t$ al. (2017), kosentrasi auksin yang semakin tinggi akan memacu sintesis etilen yang dapat menghambat perpanjangan sel sehingga pertumbuhan tanaman akan terhambat. 
Website : http://agritek.unmermadiun.ac.id/index.php/agritek

\section{Jumlah Daun Dan Luas Daun (mm2)}

Jumlah daun dan luas daun secara nyata dipengaruhi oleh faktor panjang pemangkasan batang bawah (P) bersama dengan faktor waktu pembukaan plastik okulasi (B). Rata-rata jumlah daun pada $46 \mathrm{HSO}, 53 \mathrm{HSO}$, dan $60 \mathrm{HSO}$ tersaji pada Tabel 3.dan luas daun dapat dilihat pada Gambar 2.

Tabel 3.

\begin{tabular}{|c|c|c|c|c|}
\hline & Perlakuan & 46 HSO & 53 HSO & 60 HSO \\
\hline & P1B1 & $9,53 \mathrm{~g}$ & $13,86 \mathrm{f}$ & $18,26 \mathrm{e}$ \\
\hline & P1B2 & $5,33 \mathrm{~d}$ & $9,86 \mathrm{c}$ & $13,73 \mathrm{c}$ \\
\hline & P1B3 & $2,60 \mathrm{~b}$ & $6,46 \mathrm{a}$ & $11,06 \mathrm{~b}$ \\
\hline & P2B1 & $10,66 \mathrm{~h}$ & $13,93 \mathrm{f}$ & $18,53 \mathrm{e}$ \\
\hline & P2B2 & $6,53 \mathrm{~d}$ & $11,33 \mathrm{~d}$ & $15,86 \mathrm{~d}$ \\
\hline & P2B3 & $4,06 \mathrm{c}$ & $7,93 \mathrm{~b}$ & $13,06 \mathrm{c}$ \\
\hline & P3B1 & $7,26 \mathrm{f}$ & $12,26 \mathrm{e}$ & $16,20 \mathrm{~d}$ \\
\hline & P3B2 & $4,20 \mathrm{c}$ & 8,46 b & $13,46 \mathrm{c}$ \\
\hline & P3B3 & $1,80 \mathrm{a}$ & $5,66 \mathrm{a}$ & $9,66 \mathrm{a}$ \\
\hline
\end{tabular}

Rata-rata jumlah daun bervariasi antara 1,80 - 10,66 pada pengamatan $46 \mathrm{HSO}$, antara 5,66 - 13,93 pada $53 \mathrm{HSO}$, dan 9,66 18,53 pada 60 HSO. Jumlah daun terbanyak dicapai perlakuan P2B1, namun pada pengamatan 53 HSO dan 60 HSO tidak berbeda nyata dengan perlakuan P1B1. Kecenderungan ini seiring dengan panjang tunas. Dapat dikatakan pembentukan daun sebanding dengan perpanjangan tunas. Sesuai pendapat Wahyudi et al. (2017). bahwa pertumbuhan daun berbanding lurus dengan panjang tunas, artinya semakin panjang pertumbuhan tunas maka akan semakin banyak pula pertumbuhan daun oleh proses primordial. Permulaan munculnya daun (primordia) diawali dengan pembelahan sel-sel tertentu dalam kubah ujung menjadi jaringan meristematik sehingga menghasilkan pembengkakan atau jenggul (protuberances) pada ujung batang. Kemunculan jenggul tersebut meluas dan melingkari daerah ujung pada primordia pelepah kemudian membentuk leher daun hingga helai daun. Jumlah daun akan bertambah seiring dengan panjang tunas, karena tunas yang lebih panjang menyebabkan bertambahnya jumlah ruas dan buku tempat tumbuhnya daun (Sariningtias et al., 2014).

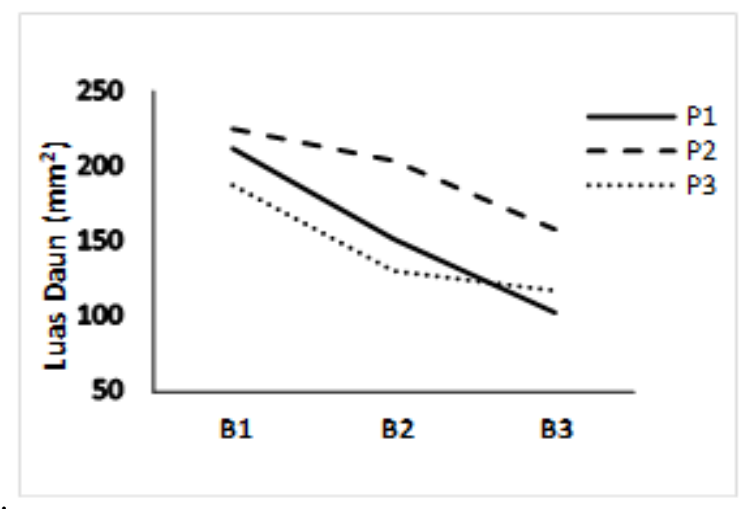

Gambar 2.

Rata-rata Luas Daun $\left(\mathrm{mm}^{2}\right)$ pada panjang pemangkasan batang bawah (P) dan waktu pembukaan plastik okulasi (B)

Gambar 2 menunjukkan bahwa rata-rata luas daun terbaik dicapai oleh kombinasi perlakuan pemangkasan $5 \mathrm{~cm}$ diatas mata tempel dengan waktu pembukaan plastik okulasi umur $25 \mathrm{HSO}$ (P2B1) yaitu 225,96 $\mathrm{mm}^{2}$. Kompabilitas batang bawah dan entres mempercepat proses penyambungan seperti yang terjadi pada okulasi dengan pemangkasan $5 \mathrm{~cm}$ diatas mata tempel. Fatur (2018) menyatakan bahwa pertautan antara entres dan batang bawah juga sangat ditentukan oleh faktor lingkungan serta pelaksanaan yang mencakup proses irisan pada entris, irisan pada batang bawah dan pemeliharaan hama dan penyakit. Jika entres yang digunakan cepat menyesuaikan dengan batang bawah maka suplai unsur hara dan hasil fotosintesis berjalan dengan lancar sehingga pertumbuhan tanaman menjadi optimal. Pembukaan plastic pada batang yang sudah menyatu di umur 25 HSO menyebabkan pertumbuhan tunas dan pembentukan daun lebih cepat sehingga terbentuk daun yang lebih luas (Kurniawati , 2014).

\section{IV.KESIMPULAN}

Panjang pemangkasan batang bawah (P) dengan waktu pembukaan plastik (B) secara bersama-sama memberikan pengaruh interaksi nyata terhadap waktu muncul tunas, panjang tunas, jumlah daun dan luas daun. Kombinasi perlakuan pemangkasan 5 $\mathrm{cm}$ diatas mata tempel dengan waktu pembukaan plastik okulasi umur 25 HSO (P2B1) memberikan hasil terbaik pada variabelvariabel tersebut. Panjang pemangkasan batang bawah (P) dan waktu pembukaan plastik (B) tidak berpengaruh nyata terhadap persentase okulasi tumbuh 
Website : http://agritek.unmermadiun.ac.id/index.php/agritek

\section{DAFTAR PUSTAKA}

Adinugraha, H. A., Hasnah T. M., dan Waris. 2017. Pertumbuhan Tunas Beberapa Klon Jati Terseleksi setelah Pemangkasan di Persemaian. Jurnal Ilmu Kehutanan. 11:109-117.

Badan Pusat Statistika. 2019. Produksi Tanaman Hortikultura. https://www.bps.go.id/subject/55/hortikultura.html\#subjekViewTab3

Basri, Z. 2009. Kejian Metode Perbanyakan Klonal pada Tanaman Kakao. Media Litbang Sulteng.2(1):7-14.

Fatur, H. R., Roedy, S., \& Nur, E. S. (2018). Pengaruh Umur Batang Bawah dan Naungan Terhadap Keberhasilan Grafting pada Tanaman Durian (Durio zibethinus Murr.) Lokal. Buana Sains. 18 (1) : 21 - 28.

Gusriani, Septirosya, T., Darmawi, A. Pertumbuhan Bibit Jeruk Asal Kuok Hasil Okulasi pada Berbagai Tingkat Naungan dan Umur Batang Bawah Agriscript.1(2):51-61

Hakim, L., Hidayat, F., Yulia, R., dan Cahirunni, A. R. 2019. Pelatihan Perbanyakan Tanaman Buah Secara Vegetatif dengan Teknik Penyambungan (Grafting) di Panti Asuhan Yayasan Islam Media Jasih Banda Aceh. Jurnal Pengabdian pada Masyarakat. 1(2): 101-106.

Hidayati, Y. 2009. Kadar Hormon Auksin Tanaman Kenaf (Hibiscus cannabinus L.) Bercabang dan Tidak Bercabang. Agrovigor. 2 (2): 89-96.

Jayanti, M. A. D., Sugiyatno, A., Roviq, M., dan Maghfoer, D. 2015. Kompatibilitas Tujuh Varietas Calon Interstock Tanaman Jeruk pada Batang Bawah Japanche citrun (JC). Jurnal Produksi Tanaman. 1-9.

Kurniawati, D., M, Santoso \& E, Widaryanto. (2014). Pertumbuhan Jenis Mata Tunas Pada Okulasi Beberapa Klon Tanaman Karet (Hevea brasiliensis Muell. Arg). Jurnal Produksi Tanaman, 6 (1) : 532-539.

Mardiyah, Basri, Z., Yusuf, R., dan Hawalina. 2017. Pertumbuhan Tunas Anggur Hitam (Vitis vinifera L.) pada Berbagai Kosentrasi Benzylamino Purin dan Indolebutyric Acid. Jurnal Agroland. 24(3): 181-189.

Margareta, F., Budianto, dan Sutoyo. 2019. Studi Tentang Perbanyakan Tanaman Jeruk Siam Pontianak (Citrus nobilis Var. Microcarpa) Secara Vegetatif Di Kebun Percobaan Putin Desa Sidomulyo Kota Batu. Berkala Ilmiah PERTANIAN 2(1): 26-29.

Musthofa, Mochammad I., Sugiyatno, A., Wardiyati, T., dan Roviq, M. 2019. Pengaruh Posisi Mata Tempel Pada Keberhasilan Okulasi Beberapa Varietas Jeruk Keprok (Citrus reticulate). Jurnal Produksi Tanaman. 7(5):867-873.

Nurwahyuni, I., Napitupulu, J. A., Rosmayati, dan Harahap, F. 2012. Pertumbuhan Okulasi Jeruk Keprok Brastepu (Citrus nobilis Var. Brastepu) Menggunakan Jeruk Asam Sebagai Batang Bawah. Jurnal Saintika. 12(1): 24-35.

Prastowo, N. H., Roshetko, J. M., Maurung, G. E. S., Nugraha, E., Tukan, J. M., Harum, F. 2006. Teknik Pembibitan dan Perbanyakan Vegetatif Tanaman Buah. World Agroforestry Centre \& Winrock International: Bogor.

Purba, E.C., dan Purwoko, B.S. 2019. Teknik Pembibitan, Pemupukan, Dan Pengendalian Hama Penyakit Tanaman Komoditi Jeruk Siam (Citrus nobilis Var. Microcarpa) Di Kecamatan Simpang Empat dan Kecamatan Payung, Kabupaten Karo, Sumatra Utara, Indonesia. Jurnal Pro-Life. 6(1):66-75.

Rochayat, Y., Amalia, A.C., dan Aini, A. 2017. Pengaruh Pemangkasan terhadap Pertumbuhan: Percabangan dan Pembesaran Bonggol Tiga Kultivar Kamboja Jepang (Adenium arabicum). Jurnal kultivasi. 16(2):382-387

Sariningtias, N. W., Poerwanto, R., dan Gunawan, E. 2014. Penggunaan Benzil Amino Purin (BAP) pada Okulasi Jeruk Keprok (Citrus reticulate). Jurnal Hortikultura Indonesia. 5(3): 158-167.

Setiono, dan Supriyanto, A. 2004. Keunggulan Teknik Perbanyakan Okulasi Irisan pada Tanaman Jeruk. Loka Penelitian Tanaman Jeruk dan Hortikultura Subtropik: Batu.

Sugiyanto, A. 2017. Potensi Penggunaan Beberapa Varietas Batang Bawah Sebagai Interstock untuk Memacu Pertumbuhan Benih Jeruk. IPTEK Hortikultura Balai Penelitian Tanaman Jeruk dan Buah Subtropika.

Wahyudi, E., Permanasari, E., dan Aryati, D. 2017. Perbedaan Batang Bawah dan Masa Penyimpanan Entres Terhadap Pertumbuhan Okulasi Bibit Jeruk Siam Madu (Citrus nobilis). Jurnal Agroteknologi. 8(1): 35-40. 